\title{
Performance and ingestive and social behavior of young cattle with different sexual conditions supplemented in Aruana pasture
}

\section{Desempenho, comportamento ingestivo e social de bovinos jovens com diferentes condições sexuais suplementados em pastagem de Aruana}

\author{
Odilene de Souza Teixeira" ${ }^{*}$; Ivan Luiz Brondani²; Dari Celestino Alves Filho²; \\ José Laerte Nörnberg ${ }^{3}$; Jonatas Cattelam ${ }^{4}$; Lucas Braido Pereira ${ }^{5}$; \\ Leonel da Silva Rodrigues ${ }^{5}$; John Lenon Klein ${ }^{6}$
}

\begin{abstract}
This study was conducted aiming at measuring the performance and behavior of beef cattle surgically castrated, immunocastrated or non-castrated, finished at 18 months old in Aruana pasture and with energy supplementation. Thirty-nine male bovines with an initial average body weight and age of $284.1 \pm 31.4$ $\mathrm{kg}$ and 14 months old, respectively, were used. The bromatological composition analysis and productive parameters of the pasture did not differ between treatments. The performance of young cattle was not changed by the sexual condition. When evaluating the agonistic behavior, the non-castrated bovine presented a higher number of activities, such as threats and fights, in relation to those immunocastrated. The time spent on the feeder by non-castrated young cattle (56.20 minutes) was higher than that observed for surgically castrated or immunocastrated (41.43 and 32.38 minutes, respectively). The combination between the correct management of Aruana pasture and use of supplementation showed to be promising for finishing bovines. Both surgically castrated and immunocastrated steers demonstrated to be equivalents in the performed evaluations. Therefore, if the farmer chooses castration, the use of immunocastration is suggested. This practice is less invasive, preserves animal welfare more than surgical castration, and has a lower cost.
\end{abstract}

Key words: Agonistic behavior. Energy supplementation. Immunocastration. Surgical castration. Time spent in the feeder.

\section{Resumo}

Objetivou-se mensurar o desempenho e comportamento de bovinos de corte, castrados cirurgicamente, imunocastrados ou não castrados, terminados aos 18 meses em pastagem de Aruana, recebendo

1 Discente, Curso de Doutorado, Programa de Pós-Graduação em Zootecnia, Universidade Federal do Rio Grande do Sul, UFRGS, Porto Alegre, RS, Brasil. E-mail: odilene rs@hotmail.com

2 Profs. Drs., Departamento de Zootecnia, Universidade Federal de Santa Maria, UFSM, Santa Maria, RS, Brasil. E-mail: ivanbrondani@gmail.com; darialvesfilho@hotmail.com

3 Prof. Dr., Departamento de Tecnologia e Ciência dos Alimentos, UFSM, Santa Maria, RS, Brasil. E-mail: jlnornberg@gmail.com

4 Prof. Dr., Universidade Federal da Fronteira Sul, UFFS, Realeza, PR, Brasil. E-mail: jonatas.cattelam@uffs.edu.br

5 Discentes, Curso de Doutorado, Programa de Pós-Graduação em Zootecnia, UFSM, Santa Maria, RS, Brasil. E-mail: braidopereira@gmail.com; rodrigues_leonel@hotmail.com

6 Discente, Curso de Mestrado, Programa de Pós-Graduação em Zootecnia, UFSM, Santa Maria, RS, Brasil. E-mail: johnlenonklein@hotmail.com

* Author for correspondence 
suplementação energética. Foram utilizados trinta e nove bovinos machos, com peso corporal e idade iniciais médios de 284,1 $\pm 31,4 \mathrm{~kg}$ e 14 meses, respectivamente. A análise da composição bromatológica e os parâmetros produtivos da pastagem não diferiram entre tratamentos. $\mathrm{O}$ desempenho dos novilhos não foi alterado pela condição sexual $(\mathrm{P}>0,05)$. Ao avaliar o comportamento agonístico, verifica-se que os não castrados apresentaram maior número de atividades, como ameaças e brigas, em relação aos imunocastrados. O tempo de permanência no comedouro dos não castrados (56,20 minutos) foi superior ao detectado para castrados cirurgicamente ou imunocastrados (41,43 e 32,38 minutos), respectivamente. A combinação entre o correto manejo da pastagem de Aruana e o uso de suplementação se mostrou promissora para a terminação de bovinos. Quando compara-se os novilhos castrados cirurgicamente e os imunocastrados ambos demostraram ser equivalentes nas condições do presente estudo. Portanto, se o produtor optar pela castração sugere-se a imunização contra o fator de liberação de gonatrofinas. Essa prática é menos invasiva, preserva o bem-estar animal mais do que a castração cirúrgica e tem menor custo.

Palavras-chave: Castração cirúrgica. Comportamento agonístico. Imunocastração. Suplementação energética. Tempo no comedouro.

\section{Introduction}

The average indices of the zootechnical performance of the Brazilian beef cattle show that the country has a potential to develop because the average slaughter weight for males is 45 months old, which is an indicator below the productive potential that can be reached under tropical pastures (CARVALHO et al., 2010). Among the tropical pastures, stands out the species Panicum maximum Jacq cv. Aruana, a medium-sized grass of clumping habit with thin stems and narrow leaves, which gives the species a high productivity and nutritional quality (BARBOSA et al., 2003).

According to Fernandes et al. (2015), to produce steers around 16 to 18 months old it is necessary a strategic combination between pasture management (Aruana) and use of food supplementation, allowing improving productivity indices since there is a synchronization between the supply of nutrients in the diet and the nutritional demand of animals (REIS et al., 2012).

In addition to nutritional factors, the sexual condition of the young cattle, castrated or noncastrated, may interfere with its performance. According to Kay and Houseman (1975), the sexual condition of the animal plays an important role in the growth pattern, body development, and carcass composition of beef cattle. According to Hernandez et al. (2005), castration has been used for years aiming at reducing the aggressive behavior, facilitating the management, and improving the carcass finishing (VAZ et al., 2014), as well as avoiding reproduction. However, the surgical castration may compromise the animal welfare since it is an invasive method. These practices must be revaluated to add less invasive characteristics even if the production systems have to be modified (OLIVEIRA et al., 2008).

The sexual condition may still modify the ingestive and social behavior due to the distinct responses of the cattle to certain situations. In this sense, Price et al. (2003) observed that non-castrated young cattle presented a tendency for aggressive interactions when compared to castrated steers. In this context, the knowledge of animal behavior assists in understanding these responses and, mainly, the phenomena that regulate the harmony of the social group because although the life in a group brings adaptive advantages, it also brings an increase in the competition for resources, resulting in the appearance of an aggressive behavior among animals (BOUISSOU; BOISSY, 2005).

Considering that, researches have been studying alternatives for bovine castration that are less painful and contribute to a higher preservation of health and welfare of animals since the modern consumers require changes of practices that nowadays are common in livestock. Thus, the use of 
the immunocastration method may result in benefits to animal welfare since this procedure does not use the surgical incision.

According to Janett et al. (2012), the immunological method represents an alternative that respects the animals when compared to surgical castration. Theubet et al. (2010) demonstrated that the immunocastration method through the administration of anti-GnRH vaccines is effective in the temporary inhibition of testicular testosterone secretion. However, immunocastration is recent in Brazil and most of the few studies found in the literature are restricted to finishing animals in a feedlot. Therefore, it is necessary to measure the performance and behavioral parameters in the pasture with the aim to understand the animal response to this new method.

Thus, the aim of this study was to measure the performance and ingestive and social behavior of beef cattle with different sexual conditions, finished at 18 months old in an Aruana pasture with energy supplementation.

\section{Materials and Methods}

The Ethics Committee on the Use of Animals of the Federal University of Santa Maria approved all the procedures that involved animals in this study, under the protocol No. 122/2014. The experiment was carried out at the Laboratory of Beef Cattle (LBC) of the Department of Animal Science of the Federal University of Santa Maria, located in Santa Maria, at the central depression of the State of Rio Grande do Sul. Regional climate is classified as humid subtropical climate, according to Köppen classification (ALVARES et al., 2013).

The total experimental area used corresponded to 8.04 ha of Aruana grass (Panicum maximum Jacq cv. Aruana) implanted in 2012. This area was divided into 12 spots with a similar area of 0.67 ha each, in which the test and regulator animals were maintained. During the experimental period, a topdressing fertilization was carried out in the area and consisted of $81 \mathrm{~kg} \mathrm{ha}^{-1}$ of the NPK fertilizer 5-20-20 and $60 \mathrm{~kg} \mathrm{ha}^{-1}$ of $\mathrm{N}$, the latter divided into two applications. The animals remained in continuous grazing with salt $(\mathrm{NaCl})$ and water ad libitum.

The experimental design was a completely randomized design with three treatments and four sub-periods. The experimental period was from January to April, totaling 112 days, divided into four sub-periods of 28 days. Thirty- nine male bovines, contemporary, with an initial average body weight (BW) and age of $284.1 \pm 31.4 \mathrm{~kg}$ and 14 months old, respectively, were used. Previously to the study, the animals were balanced according to the body weight, being maintained under the same nutritional, sanitary, and environmental conditions. Treatments were based on the bovine sexual condition and consisted of surgically castrated, immunocastrated or non-castrated bovines, with four replications of area per treatment and a variable number of animals within repetitions. The animals were originated from the continuous alternate crossbreed between Charolais and Nellore from the LBC experimental herd. Previously to the study, all animals were submitted to a treatment with the injectable parasiticide abamectin at $1 \%$.

Surgical castration was performed by two veterinarians. Previously to the surgery, the animals were contained in a squeeze chute and the scrotum sanitation was performed with $70 \%$ ethyl alcohol. The technique used for castration was the open orchiectomy by removing the apex of the scrotum with the use of a scalpel (blade No. 24). The drugs used in the surgical procedure were based on the combination of local anesthetic by the blocking with lidocaine at a dose of $7 \mathrm{~mL}$ at each spermatic cord and the anti-inflammatory flunixin meglumine at a dose of $1.1 \mathrm{mg} \mathrm{kg}^{-1}$ via intramuscular. This procedure followed Webster et al. (2013), who identified a lower stress in castrated bovines when these drugs were used, which was measured by the levels of the cortisol hormone in the blood. In addition to these drugs, the antibiotic oxytetracycline was used at a 
dose of $1 \mathrm{~mL} 10 \mathrm{~kg}^{-1}$ of body weight. The antibiotic and anti-inflammatory were administered on the castration day and 2, 4, and 6 days after castration together with a healing/repellent spray near the surgical incision. Surgical castration was 50\% more expensive than the immunological castration due to costs with drugs and veterinarian.

The immunocastration method consisted of three doses of vaccine that acts against the gonadotropinreleasing factor. The animals belonging to this treatment received the first, second, and third doses at 11,12 , and 15 months of age, respectively, the vaccine application protocol was administered by a technician recognized by the produc manufacturing company. Castrations (surgical and immunocastration) were performed at 12 months of age in order to allow the comparison between treatments.

The diet provided to the animals was calculated according to NRC (2000) in order to meet the nutritional requirements of animals under pasture and had the aim at reaching a gain close to $1.2 \mathrm{~kg}$ day $^{-1}$, being estimated a dry matter intake of $2.5 \mathrm{~kg}$ $100 \mathrm{~kg}^{-1}$ of body weight. The diet was composed by Aruana grass and a supplementation equivalent to $1 \%$ of body weight. The supplementation was provided daily at $2 \mathrm{p} . \mathrm{m}$. in plastic feeders with an availability of 0.66 meters of feed trough per animal. The animals consumed the entire supplement provided. The supplement was composed by following ingredients: $62.7 \%$ of oat grain, $35.0 \%$ of corn grain, $1.0 \%$ of urea, and $1.3 \%$ of limestone. The nutritional composition of the diet was $13 \%$ of crude protein and $69 \%$ of total digestible nutrients.

The Aruana pasture was managed to aim at maintaining the forage mass around $2600 \mathrm{~kg} \mathrm{DM}$ $\mathrm{ha}^{-1}$. For this, the continuous stocking system with a variable number of regulator animals was used through the put-and-take technique of Mott and Lucas (1952). The forage mass determination was performed by the method of double sampling, as described by Wilm et al.(1944), being the evaluations performed at the beginning and middle of the experimental sub-period. Samples were randomly taken, five of them cut close to the ground $(0.25$ $\mathrm{m}^{2}$ sample $^{-1}$ ) and other twenty visually evaluated in the total area of the spot. Homogenized samples of each cut were collected in order to estimate the dry matter content and to the quantitative evaluation of the pasture by structural separation for determining the leaf blade: stem ratio.

The leaf blade mass of the pasture was obtained by multiplying the percentage of leaf blade by the forage mass. The canopy height of Aruana grass was determined twice in each experimental sub-period in the break between the double samplings aiming at monitoring the forage mass. In each evaluation, 50 readings were taken by spot using a graduated ruler. The estimation of the daily accumulation rate of forage dry matter was determined at each experimental sub-period of 28 days with three pasture exclusion cages per spot by determining the amount of mass existing at the beginning and end of each experimental sub-period and dividing it by the number of days of periods, according the methodology described by Klingmann et al. (1943).

The animal load was calculated in order to obtain the forage offer by the sum of the average weight of test animals and the average weight of each regulator animal, multiplying it by the number of days these animals remained in the pasture and dividing the result by the total number of grazing days. From the values of forage mass, pasture accumulation rate, and animal load, the forage offer was determined in $\mathrm{kg}$ of DM $100 \mathrm{~kg}$ of $\mathrm{LW}^{-1}$, as the formula:

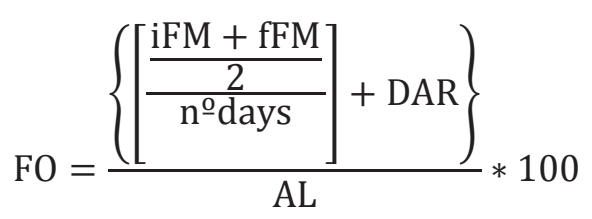

in which FO is the forage offer in the period, $\mathrm{iFM}$ is the initial forage mass in the period, fFM is the final forage mass in the period, DAR is the daily accumulation rate of DM in the period, $\mathrm{AL}$ is the animal load in the period (GLIENKE et al., 2010). 
The leaf blade offer was measured by multiplying the percentage of leaf blades by the forage offer.

The representative sample of forage ingested by the young cattle was collected in each period by the method of simulated grazing in which the observer evaluated the height and the structural part of the plant ingested by the animal. Subsequently, a similar portion of the plant ingested was obtained manually (EUCLIDES et al., 1992). These samples were pre-dried in a forced circulation kiln at $55^{\circ} \mathrm{C}$ for 72 hours until a constant weight. After dried, the samples were milled in a Willey type mill with a 1 mm sieve.

The dry matter, organic matter, total nitrogen, and ether extract of forage samples were determined by the AOAC methodology (AOAC, 1995). The neutral detergent fiber and acid detergent fiber contents were determined according to Van Soest et al. (1991). The neutral detergent insoluble nitrogen and acid detergent insoluble nitrogen contents followed the methodology of Licitra et al. (1996). The total digestible nutrients were calculated from the chemical composition of the feed through the methodology of Weiss et al. (1992).

The monitoring of animal performance was performed by weighing the animals at the beginning and end of each experimental sub-period, respecting a 12-hour fasting of liquids and solids. Thus, the daily average weight gain of animals in each subperiod was calculated by the difference in weight between weighing, divided by the number of days in the period. The total body weight gain per hectare ( $\mathrm{kg}$ of $\mathrm{LW} \mathrm{ha}{ }^{-1}$ ) was obtained by the product of the daily average weight gain $\left(\mathrm{kg}\right.$ animal $\left.{ }^{-1}\right)$ of test animals with the number of animals day per hectare (product of the average stocking rate, in animals $\mathrm{ha}^{-1}$ and the number of grazing days), according to Santos et al. (2008).

The animal body was measured at the beginning and end of the experiment with a hipometer and graduated ruler. Bovines were immobilized in a squeeze chute in order to obtain the following measurements: body length, withers height by using the methodology of Menezes et al. (2008), and scrotal circumference (OSORIO et al., 2014).

At the beginning and end of the experimental period, the measurements of area of the Longissimus dorsi muscle (rib eye area, $\mathrm{cm}^{2}$ ) and subcutaneous fat thickness at the $12^{\text {th }}$ and $13^{\text {th }}$ rib region were taken by capturing images using the ALOKA SSD 500 ultrasound, being their interpretation performed by the BIOTRONIC - BioSoft Toolbox ${ }^{\circledR}$ program.

The observations of ingestive and social behavior were performed in two spots of each treatment, containing three and four animals each, totaling seven animals evaluated per treatment in each observation period. The ingestive behavior observation lasted 24 uninterrupted hours, starting and ending at $8 \mathrm{a} . \mathrm{m}$. In order to assist in determining the animal activities at the nighttime, 19 LED flashlights were used, allowing observing the young cattle from a certain distance and minimizing the interference on their routine. Regarding the ingestive behavior, the activities of grazing, idle, and rumination were registered every 10 minutes. Grazing time was considered the period in which occurred the practice of capturing the forage by the animal, including small displacements. Rumination time was considered the period in which the animal was not grazing but chewing the ruminal bolus. The idle time represented the period in which the animal was not grazing nor ruminating, being included the social activities and water ingestion.

For the evaluation of social behavior, the animals were observed for 12 hours, starting at 8 a.m. and ending at 8 p.m. Regarding the social behavior, agonistic activities (aggressive) of threats and fights and non-agonistic activities, such as smelling, licking, breeding attempt (mounting), and interaction with objects, were observed by registering the number of times the animal executed these activities. We considered as interaction with objects when the bovine interacted with the feeder, drinking fountain, gate, fence, and grazing exclusion cages. For smelling, licking, and breeding attempt, we observed when two animals executed these 
behaviors. The threat behavior was characterized by the retreat of an animal with the approach of an aggressor or the teasing of scraping the floor. The practice of fighting was considered when the animals entered into disputes with body aggressions among them, being this methodology of social behavior adapted from Cattelam et al. (2014).

The experimental design was a completely randomized design with three treatments and four sub-periods divided in time. The collected data were tested regarding the normality by the KolmogorovSmirnov test, being performed adjustments when necessary through the logarithmic transformation or using the Kruskal-Wallis test for variables that did not present normal distribution. Subsequently, the data were submitted to the analysis of variance and F-test by the PROC MIXED procedure for the variables of ingestive and social behavior and PROC GLM for the variables related to animal performance and productive parameters of pasture $(\mathrm{P}<0.05)$. When differences were observed in the analyzed variables, the means were compared by the Student t-test at 5\% significance level. For the variable social behavior, the non-parametric test of Kruskal-Wallis was used. The statistical package SAS (Statistical Analysis System, version 9.2) was used for all statistical analysis.

\section{Results and Discussion}

No difference was observed for the bromatological variables of the Aruana pasture on the grazing simulation according to the sexual condition of young cattle, which means that the material taken by the animals was similar in terms of pasture structure (Table 1). The values of crude protein $(\mathrm{CP})$ and total digestible nutrients (TDN) of the Aruana pasture (14.66 and 53.24\%, respectively) showed that this forage could be a good option to optimize beef cattle production. Grasses of the species Panicum maximum, such as Aruana, are among the most used in animal production in Brazil due to their good adaptation to tropical and subtropical climates, good nutritional value, and high animal production (GOMES et al., 2011).

In general, the productive variables that characterize the Aruana grass pasture did not differ $(\mathrm{P}>0.05)$ between treatments (Table 1), which is related to the similarity of management used in the pasture and animals during the experimental period, aiming at offering a pre-established forage mass at the beginning of the experiment of $2600 \mathrm{~kg} \mathrm{DM} \mathrm{ha}^{-1}$. According to Minson (1990), dry matter availability must be above the suggested value of $2000 \mathrm{~kg}$ of $\mathrm{DM} \mathrm{ha}^{-1}$ so as not to compromise animal intake.

Table 1. Bromatological composition (grazing simulation) and productive characteristics of the Aruana pasture according to the sexual condition of the cattle.

\begin{tabular}{lcccc}
\hline \multirow{2}{*}{ Bromatological composition } & \multicolumn{3}{c}{ Sexual condition } & \multirow{2}{*}{ Value $\mathrm{P}^{1}$} \\
\cline { 2 - 4 } & Castrated & Immunized & Non-castrated & 0.2073 \\
\hline DM, \% & $27.81 \pm 0.39$ & $26.82 \pm 0.39$ & $27.16 \pm 0.39$ & 0.7469 \\
OM, \% & $89.40 \pm 0.28$ & $89.37 \pm 0.28$ & $89.65 \pm 0.28$ & 0.5847 \\
CP, \% & $14.33 \pm 0.40$ & $14.76 \pm 0.40$ & $14.90 \pm 0.40$ & 0.9597 \\
NDF, \% & $72.07 \pm 0.37$ & $72.11 \pm 0.37$ & $72.22 \pm 0.37$ & 0.2161 \\
ADF, \% & $40.12 \pm 0.50$ & $39.09 \pm 0.50$ & $38.99 \pm 0.50$ & 0.4916 \\
EE, \% & $1.92 \pm 0.05$ & $2.00 \pm 0.05$ & $1.97 \pm 0.05$ & 0.5548 \\
TDN, \% & $52.62 \pm 0.56$ & $53.27 \pm 0.56$ & $53.44 \pm 0.56$ & \\
\hline
\end{tabular}


continuation

\begin{tabular}{|c|c|c|c|c|}
\hline Productive characteristics & & & & \\
\hline FM, kg DM ha' & $2641.58 \pm 108.16$ & $2722.91 \pm 108.16$ & $2810.39 \pm 108.16$ & 0.5774 \\
\hline LBM, kg DM ha- ${ }^{-1}$ & $817.77 \pm 58.36$ & $844.18 \pm 58.36$ & $894.37 \pm 58.36$ & 0.6431 \\
\hline $\mathrm{L}: \mathrm{S}$ & $0.77 \pm 0.06$ & $0.75 \pm 0.06$ & $0.78 \pm 0.06$ & 0.9558 \\
\hline FAR, kg DM ha ${ }^{-1}$ day $^{-1}$ & $67.78 \pm 7.16$ & $76.11 \pm 7.65$ & $62.64 \pm 7.39$ & 0.4501 \\
\hline $\mathrm{FO}, \mathrm{kg} \mathrm{DM} 100^{-1} \mathrm{~kg} \mathrm{BW}$ & $8.85 \pm 0.58$ & $10.27 \pm 0.58$ & $8.79 \pm 0.58$ & 0.1400 \\
\hline LBO, $\mathrm{kg}$ DM $100^{-1} \mathrm{~kg} \mathrm{BW}$ & $2.57 \pm 0.30$ & $3.06 \pm 0.30$ & $2.63 \pm 0.30$ & 0.5893 \\
\hline $\mathrm{CH}, \mathrm{cm}$ & $21.97 \pm 1.47$ & $22.27 \pm 1.47$ & $22.59 \pm 1.47$ & 0.9790 \\
\hline
\end{tabular}

${ }^{1} \mathrm{P}=$ Probability. $\mathrm{DM}=$ dry matter; $\mathrm{OM}$ : organic matter; $\mathrm{CP}=$ crude protein; $\mathrm{NDF}=$ neutral detergent fiber; $\mathrm{ADF}=$ acid detergent fiber; $\mathrm{EE}=$ ether extract; $\mathrm{TDN}=$ total digestible nutrients; $\mathrm{FM}=$ forage mass; $\mathrm{LBM}=$ leaf blade mass; $\mathrm{L}: \mathrm{S}=$ leaf blade:stem ratio; $\mathrm{FAR}=$ forage accumulation rate $\mathrm{FO}=$ forage offer; $\mathrm{LBO}=$ leaf blades offer; $\mathrm{CH}=$ canopy height.

The leaf blades mass presented an average of $852.11 \mathrm{~kg} \mathrm{ha}^{-1}$ and was close to the data reported by Emerenciano Neto et al. (2013), who found $802.9 \mathrm{~kg}$ $\mathrm{ha}^{-1}$ for the Aruana grass managed at $25 \mathrm{~cm}$ of height at post-grazing. The percentage of leaf blades was higher than $30 \%$ of the forage mass regardless of the treatment, leading to a leaf blade: stem ratio of 0.77 $\mathrm{kg}$ of leaf $\mathrm{kg}^{-1}$ of the stem. This finding shows that the pasture has a good quality due to the expressive participation of leaf blades, characterized by long and narrow leaves with thin stems. Pompeu et al. (2010) observed that the structural behavior of the canopy of the Aruana pasture is able to provide diets with a high proportion of leaf blades for animal grazing. According to Silva et al. (2009), among the structural components of the pasture, the highest nutritive value is found in the leaves.

Regarding the accumulation rate, an average of $68.84 \mathrm{~kg} \mathrm{DM} \mathrm{ha}^{-1}$ day $^{-1}$ was obtained for the treatments at 112 days of evaluation. During the experimental period, the average precipitation was $56.3 \%$ in March, which is above the historical average, causing 10 days of precipitation. However, the opposite was observed in April, which had a precipitation deficit of $30.4 \%$ (INMET, 2015). This fact may have led to a lower forage accumulation rate. Pacheco et al. (2014) worked with millet and Sudan grass pasture and demonstrated that weather variables influenced the productive characteristics of pasture.
The recommended value for forage offer according to Hodgson and Brooks (1999) is close to $10 \%$ of the body weight. In our study, the diet was calculated for an intake of $2.5 \%$ of the body weight according to NRC (2000) and the treatments had an average forage offer of $9.3 \%$. In this sense, Braga et al. (2007) evaluated four forage offers of Marandu grass $(5,10,15$, and $20 \%$ of the body weight) and verified that the best animal performance occurred at an offer of $10 \%$. The offer of leaf blades of Aruana pasture did not change $(\mathrm{P}=0.5893)$, demonstrating a uniformity on the pasture management among the treatments.

Pasture height was also used to measure the productivity patterns of forage, mainly to monitor the forage mass. Cano et al. (2004) demonstrated that pasture management by canopy height assists in controlling the forage mass. Zanini et al. (2012) studied the Aruana grass for ovine production and identified that the ideal range to manage this pasture, avoiding difficulties of capture and ingestion of forage, is a height of 15 to $30 \mathrm{~cm}$, which was also observed in our study.

The variables related to the performance of young cattle (Table 2 ) did not undergo the influence of the sexual condition $(\mathrm{P}>0.05)$. Most of the studies that evaluated the performance of animals under different sexual conditions concluded that non-castrated animals had a higher potential for 
weight gain (ÍTAVO et al., 2008; LOPES et al., 2011; SANTOS et al., 2014), which is due to the higher participation of androgen hormones, mainly the testosterone (VITTORI et al., 2006). However, in our study, steer castration was performed at a more advanced age (12 months) and the animals were benefited by the anabolic effect of testosterone for a long time. In addition, the experimental conditions were similar between treatments, with the same breed pattern, similar ages, and the same diet. In this sense, Rodriguez et al. (2014) did not observe differences in the performance of bulls and steers maintained on a tropical pasture. Similarly, Amatayakul-Chantler et al. (2012) did not find differences in the performance of non-castrated animals and immunocastrated young cattle.

Table 2. Initial and final weights, average daily gain and weight gain per hectare of cattle according to the sexual condition.

\begin{tabular}{lcccc}
\hline \multirow{2}{*}{\multicolumn{1}{c}{ Variables }} & \multicolumn{3}{c}{ Sexual condition } & \multirow{2}{*}{ Value $\mathrm{P}^{1}$} \\
\cline { 2 - 4 } & Castrated & Immunized & Non-castrated & \\
\hline Initial body weight, $\mathrm{kg}$ & $287.6 \pm 8.70$ & $274.71 \pm 9.06$ & $290.14 \pm 8.39$ & 0.4259 \\
Final body weight, $\mathrm{kg}$ & $421.61 \pm 12.15$ & $391.29 \pm 12.65$ & $412.82 \pm 11.71$ & 0.2216 \\
Average daily gain, $\mathrm{kg}$ & $1.20 \pm 0.05$ & $1.04 \pm 0.05$ & $1.09 \pm 0.05$ & 0.0849 \\
${\text { Weight gain, } \mathrm{kg} \mathrm{ha}^{-1}}^{707.82 \pm 59.88}$ & $636.68 \pm 59.88$ & $703.94 \pm 59.88$ & 0.6428 \\
\hline
\end{tabular}

${ }^{1} \mathrm{P}=$ Probability.

The final weight obtained at different sexual conditions presented an average of $408.0 \mathrm{~kg}$, which is within the range of weight acceptable by the slaughterhouse industry for commercialization, mainly because the product referred to bovines finished at 18 months old and because they belonged to a genetic group not considered as premature. The daily average gain of animals was close to that stipulated at the beginning of the experiment, with an average of $1.11 \mathrm{~kg}$. This value is satisfactory for bovines under grazing systems because it takes more energy to find the feed when compared to feedlot animals. Andreo et al. (2013) found a significant difference for the average daily gain in feedlot of immunocastrated or non-castrated animals, with values of 1.06 and $1.23 \mathrm{~kg}$, respectively.

The weight gain per hectare of young cattle in Aruana pasture did not present a difference between the evaluated sexual conditions since this gain is directly influenced by the daily average gain presented in Table 2, which also did not differ. Weight gains per hectare were relatively high in relation to studies performed with tropical pastures, such as that of Corrêa (2001), who found a gain of $491.00 \mathrm{~kg} \mathrm{ha}^{-1}$ for heifers on a pasture of Panicum maximum Jacq cv. Mombaça fertilized with 200 $\mathrm{kg}$ of nitrogen per hectare. However, in our study, we used a supplementation of $1 \%$ of the body weight. Pötter et al. (2010) emphasized that the use of supplement increases the weight gain per area, making the livestock system more efficient and profitable.

In the analysis the agonistic behavior of young cattle in the pasture (Table 3), non-castrated animals presented a higher number of activities, such as threats and fights, when compared to immunocastrated bovines. This result may be due to a reflection of the presence of circulating testosterone in non-castrated animals. However, surgically castrated steers obtained intermediate results for these behaviors. This result was not clear in our research since Dunshea et al. (2005) and Vittori et al. (2007) reported that non-castrated animals have a more aggressive behavior. However, this behavioral response may be associated with the time of animals in the feeder. In that, the animals that 
took more time in the feeder had a higher number of agonistic interactions (Table 3).

Bouissou and Boissy (2005) reported that the frequency of agonistic interactions tends to decrease when a group of animals has formed a long time ago because it is a way of social dominance. Marti et al.
(2015) evaluated calves with 257 days of age under different sexual conditions and observed that noncastrated animals presented a higher incidence of combat and teasing with the heads when compared to those castrated with bands or vaccinated against the gonadotropin-releasing factor.

Table 3. Social and ingestive behavior of cattle according to the sexual condition.

\begin{tabular}{lcccc}
\hline \multirow{2}{*}{ Social behavior } & \multicolumn{3}{c}{ Sexual condition } & \multirow{2}{*}{ Value $\mathrm{P}^{1}$} \\
\cline { 2 - 4 } Threat & Castrated & Immunized & Non-castrated & 0.0392 \\
Fight & $2.06 \pm 0.47^{\mathrm{AB}}$ & $1.68 \pm 0.47^{\mathrm{B}}$ & $2.92 \pm 0.47^{\mathrm{A}}$ & 0.0042 \\
Smell & $0.83 \pm 0.24^{\mathrm{AB}}$ & $0.21 \pm 0.24^{\mathrm{B}}$ & $1.19 \pm 0.24^{\mathrm{A}}$ & 0.0519 \\
Interaction with object & $0.77 \pm 0.29$ & $1.56 \pm 0.29$ & $1.62 \pm 0.29$ & 0.0014 \\
Lick & $1.05 \pm 0.34^{\mathrm{B}}$ & $3.23 \pm 0.34^{\mathrm{A}}$ & $1.38 \pm 0.34^{\mathrm{AB}}$ & 0.2279 \\
Breeding attempt & $2.34 \pm 0.71$ & $3.66 \pm 0.71$ & $3.23 \pm 0.71$ & 0.9349 \\
\hline Ingestive behavior & $0.96 \pm 0.30$ & $1.11 \pm 0.30$ & $0.83 \pm 0.30$ & 0.5036 \\
\hline Grazing & $442.86 \pm 13.92$ & $465.71 \pm 13.92$ & $450.95 \pm 13.92$ & 0.6574 \\
Idle & $593.81 \pm 20.97$ & $595.24 \pm 20.97$ & $570.95 \pm 20.97$ & 0.7248 \\
Rumination & $361.90 \pm 15.46$ & $346.67 \pm 15.46$ & $361.90 \pm 15.46$ & $<.0001$ \\
Feeder (trough) & $41.43 \pm 2.57^{\mathrm{b}}$ & $32.38 \pm 2.57^{\mathrm{c}}$ & $56.20 \pm 2.57^{\mathrm{a}}$ & \\
\hline
\end{tabular}

${ }^{1} \mathrm{P}=$ Probability. ${ }^{\mathrm{A} B \mathrm{~B}}$ Means followed by different letters in the row differ from each other by the non-parametric Kruskal-Wallis test.

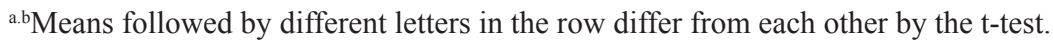

In addition, immunocastrated animals spent the time in idle with non-aggressive activities, represented by the interaction of the young cattle with objects in detriment of aggressive activities (threat and fight), as well as presented a similar sexual condition (breeding attempt) when compared to the other treatments. Jago et al. (1997) and Price et al. (2003) demonstrated that the aggressive behavior of immunocastrated animals is more similar to surgically castrated steers than to bulls.

Recently, Freitas et al. (2015) evaluated the frequency of breeding attempt of young cattle in a collective feedlot and found a lower activity of breeding attempt for surgically castrated animals, while immunocastrated and non-castrated did not differ from each other. However, this type of observation among the different sexual conditions is not scientifically explored very much, being necessary more studies due to the variability of the behavioral characteristics.

In addition to the social behavior, another important point that also justifies the nonsignificance of performance (Table 2) refers to the variables grazing time, idle, and rumination (Table 3), which did not change according to the different sexual condition $(\mathrm{P}>0.05)$. This result is due to the homogeneity of forage material collected by the young cattle, uniformity of pasture characteristics (Table 1), and the same level of supplementation, which resulted in a similar response to these characteristics.

Regardless of the treatment, the animals remained more time in idle than in grazing, which may be due to the supplementation of $1 \%$ of the body weight that the animals received daily. This 
result is in accordance with Lee et al. (2013), who observed that supplement intake might complement the nutritional needs and hence reduce the grazing time. In other words, bovines would be less dependent on the pasture as a feed source since they have a higher efficiency in nutrient intake (per unit of time) when receiving supplementation (KRYSL; HESS, 1993). These authors observed that when the amount of grains (corn) in the diet of bovines in pasture increases, the grazing time decreases.

The time spent at the feeders (trough) of noncastrated animals (56.20 minutes) was higher to that detected for those surgically castrated or immunocastrated (41.43 and 32.38 minutes, respectively). This behavior tends to increase, mainly in the dispute for food, causing a longer time in the feeder since at this moment the animals are submitted to smaller spaces in the trough, allowing them to be closer to each other. This behavior is in accordance with the results of interactions of threat and fight since immunocastrated steers presented a shorter time at the feeder, which is due to their lower agonistic activity. Surgically castrated steers presented a medium time at the feeder when compared to the other treatments, which explains the intermediate behavior in activities of fight and threat.

Cattelam et al. (2014) verified that steers in feedlot presented a higher number of competitive meetings in periods near the feeding time, decreasing animal welfare and performance (GONZÁLEZ et al., 2008). The restlessness of animals during the feeding consequently reflects in the time of feed intake, which, according to Broom and Fraser (2010), is directly related to fights and competitive meetings. These authors observed that the animals know each other, give way for some of them and get ahead of others in a consistent way.

In order to avoid social conflicts of noncastrated animals at the feeding moment, it is suggested physical modifications at the feeders, using separators between troughs, leaving it with individual access. Another alternative is the supplement supply in more than one place on the spot. Thus, it would decrease the aggressive interactions among animals, considering that only animals with a higher relationship would remain close. According to Fraser and Broom (2002), the use of the available resources performed in restrict places makes evident the competition for food among animals.

The initial body measures of bovines are similar between the three sexual conditions of animals, thus demonstrating a uniformity of treatments at the beginning of the experiment (Table 4).

The final body length showed to be higher for surgically castrated animals. For immunocastrated, an intermediate behavior was observed while for non-castrated animals, a shorter length was observed. In the phenotypic correlation analysis, the characteristic of the final length was correlated with the final weight $(0.56)(\mathrm{P}<0.001)$. However, the final body weight of beef cattle showed no difference between treatments.

Table 4. Initial and final body measurements of cattle according to the sexual condition.

\begin{tabular}{lcccc}
\hline \multirow{2}{*}{ Variables } & \multicolumn{3}{c}{ Sexual condition } & \multirow{2}{*}{ Value $\mathrm{P}^{1}$} \\
\cline { 2 - 4 } & Castrated & Immunized & Non-castrated & \\
\hline Initial thoracic circumference, $\mathrm{m}$ & $1.54 \pm 0.02$ & $1.53 \pm 0.02$ & $1.51 \pm 0.02$ & 0.5133 \\
Final thoracic circumference, $\mathrm{m}$ & $1.80 \pm 0.02$ & $1.74 \pm 0.02$ & $1.77 \pm 0.02$ & 0.1528 \\
Initial body length, $\mathrm{m}$ & $1.22 \pm 0.02$ & $1.25 \pm 0.02$ & $1.24 \pm 0.02$ & 0.7995 \\
Final body length, $\mathrm{m}$ & $1.35 \pm 0.01^{\mathrm{a}}$ & $1.32 \pm 0.01^{\mathrm{ab}}$ & $1.30 \pm 0.01^{\mathrm{b}}$ & 0.0161
\end{tabular}


continuation

Initial scrotal circumference, $\mathrm{cm}$

Final scrotal circumference, $\mathrm{cm}$

Initial rib eye area, $\mathrm{cm}^{2}$

Final rib eye area, $\mathrm{cm}^{2}$

Initial subcut. fat thickness, mm

Final subcut. fat thickness, $\mathrm{mm}$

$\begin{array}{cccc}- & 0.23 \pm 0.01 & 0.25 \pm 0.01 & 0.1765 \\ - & 0.23 \pm 0.007^{\mathrm{b}} & 0.30 \pm 0.006^{\mathrm{a}} & <.0001 \\ 45.13 \pm 1.40 & 46.06 \pm 1.40 & 47.26 \pm 1.30 & 0.5385 \\ 58.35 \pm 2.23 & 58.38 \pm 2.14 & 61.03 \pm 1.98 & 0.5732 \\ 2.58 \pm 0.17 & 2.57 \pm 0.19 & 2.65 \pm 0.16 & 0.9127 \\ 4.19 \pm 0.34 & 4.64 \pm 0.37 & 3.53 \pm 0.32 & 0.0850 \\ 1.61 \pm 0.28^{\mathrm{ab}} & 2.07 \pm 0.28^{\mathrm{a}} & 0.88 \pm 0.26^{\mathrm{b}} & 0.0123\end{array}$

${ }^{1} \mathrm{P}=$ Probability. ${ }^{\mathrm{a} b} \mathrm{M}$ Means followed by different letters in the row differ from each other by the student t-test $(\mathrm{P}<0.05)$.

The scrotal circumference at the end of the experiment differed $(\mathrm{P}<0.05)$ between sexual conditions: immunocastrated animals had $25 \mathrm{~cm}$ and those non-castrated, $30 \mathrm{~cm}$. Immunocastrated animals presented stability of testicle growth after immunization against $\mathrm{GnRH}$, which was predictable due to the maintenance of antibodies anti-GnRH in the blood circulation, causing the suppression of their reproductive functions. Similar results were found by Zanella et al. (2009), who worked with immunized bulls with the anti-hormone releasing hormone luteinizing vaccine and did not find differences for the scrotal circumference before and after immunization, with values of 21.19 and $22.0 \mathrm{~cm}$, respectively. D'Occhio et al. (2001) observed that zebuine bovines with 10 months of age maintained in a natural pasture and immunized with the anti-GnRH vaccine presented a regression in testicle size.

In addition, immunocastrated animals presented a higher subcutaneous fat deposition rate measured at the $12^{\text {th }}$ rib when compared to those noncastrated, while surgically castrated steers presented an intermediate behavior between the categories. This variable is inversely related to the number of agonistic interactions (threats and fight) in cattle (Table 3). Therefore, it is suggested that a higher agonistic interaction of non-castrated and surgically castrated animals causes a higher energy demand for maintenance, thus limiting the gain of subcutaneous fat thickness. In this sense, Amatayakul-Chantler et al. (2012) and Andreo et al. (2013) verified that immunocastrated animals presented a marked increase in the subcutaneous fat when compared to bulls. Amatayakul-Chantler et al. (2013) evaluated surgically castrated or immunocastrated animals and did not find difference for this characteristic. Freitas et al. (2015) found a similar response to that observed in our study, in which immunocastrated animals obtained a higher cover fat gain, followed by an intermediate behavior for the surgically castrated animals, and lower gain of fat thickness for those non-castrated.

\section{Conclusion}

The combination between the correct management of the Aruana pasture and the use of supplementation showed to be promising for finishing bovines with different sexual conditions at 18 months of age, considering that no difference was observed for the daily average gain, final weight, and body weight gain per hectare. In addition, all treatments presented a satisfactory fat thickness for the slaughter industry $(>3 \mathrm{~mm})$.

Surgically castrated and immunocastrated steers showed an equivalence under the conditions of this study. Therefore, if the farmer chooses for castrating the animals, it is suggested to use immunocastration. This practice is less invasive, preserves animal welfare more than surgical castration, and has a lower cost. 


\section{Acknowledgments}

This study was financed in part by the Coordenação de Aperfeiçoamento de Pessoal de Nível Superior - Brasil (CAPES) - Finance Code 001.

\section{References}

ALVARES, C. A.; STAPE, J. L.; SENTELHAS, P. C.; GONÇALVES, J. L. M.; SPAROVEK, G. Köppen's climate classification map for Brazil. Meteorologische Zeitschrift, Stuttgart, v. 22, n. 6, p. 711-728, 2013.

AMATAYAKUL-CHANTLER, S.; HOE, F.; JACKSON, J. A.; ROCA, R. O.; STEGNER, J. E.; KING, V.; HOWARD, R.; LOPEZ, E.; WALKER, J. Effects on performance and carcass and meat quality attributes following immunocastration with the gonadotropin releasing factor vaccine Bopriva or surgical castration of Bos indicus bulls raised on pasture in Brazil. Meat Science, Amsterdam, v. 95, n. 1, p. 78-84, 2013.

AMATAYAKUL-CHANTLER, S.; JACKSON, J. A.; STEGNER, J.; KING, V.; RUBIO, L. M. S.; HOWARD, R.; LOPEZ, E.; WALKER, J. Immunocastration of Bos indicus $\times$ Brown Swiss bulls in feedlot with gonadotropinreleasing hormone vaccine Bopriva provides improved performance and meat quality. Journal of Animal Science, Champaign, v. 90, n. 11, p. 3718-3728, 2012.

ANDREO, N.; BRIDI, A. M.; TARSITANO, M. A.; PERES, L. M.; BARBON, A. P. A.C.; ANDRADE, E. L.; PROHMANN, P. E. F. Influência da imunocastração $\left(\right.$ Bopriva $\left.^{\circledR}\right)$ no ganho de peso, características de carcaça e qualidade da carne de bovinos Nelore. Semina: Ciências Agrárias, Londrina, v. 34, n. 6, p. 4121-4132, 2013.

ASSOCIATION OF OFFCIAL ANALYTICAL CHEMISTRY - AOAC. Official methods of analyses. $16^{\text {th }}$ ed. Arlington: AOAC International, $1995.1025 \mathrm{p}$.

BARBOSA, C. M. P.; BUENO, M. S.; CUNHA, E. A.; SANTOS, L. E.; ESTRADA, L. H. C.; QUIRINO, C. R.; SILVA, J. F. C. Consumo voluntário e ganho de peso de borregas das raças Santa Inês, Suffolk e Ile de France, em pastejo rotacionado sobre Panicum maximum jacq. cvs Aruana ou Tanzânia. Boletim da Indústria Animal, Nova Odessa, v. 60, n. 1, p. 55-62, 2003.

BOUISSOU, M. F.; BOISSY, A. Le comportement social des bovins et ses conséquences en élevage. INRA Productions Animales, Saint-Genès-Champanelle, v. 18, n. 2, p. 87-99, 2005.
BRAGA, G. J.; PEDREIRA, C. G. S.; HERLING, V. R.; LUZ, P. H. C. Eficiência de pastejo de capim-marandu submetido a diferentes ofertas de forragem. Pesquisa Agropecuária Brasileira, Brasília, v. 42, n. 11, p. 16411649, 2007.

BROOM, D. M.; FRASER. A. F. Comportamento e bemestar de animais domésticos. 4. ed. São Paulo: Manole, 2010. 438 p.

CANO, C. C. P.; CECATO, U.; CANTO, M. W.; RODRIGUES, A. B.; JOBIM, C. C.; RODRIGUES, A. M.; GALBEIRO, S.; NASCIMENTO, W. G. Produção de forragem do capim-tanzânia (Panicum maximum Jacq. cv. Tanzânia-1) pastejado em diferentes alturas. Revista Brasileira de Zootecnia, Viçosa, MG, v. 33, n. 6, p. 1949-1958, 2004.

CARVALHO, D. M. G.; ZERVOUDAKIS, J. T.; CABRAL, L. S.; OLIVEIRA, A. A.; KOSCHECK, J. F. W.; BENATTI, J. M. B.; SILVA, J. J. Suplementação de bovino sem sistema de pastejo: aspectos relacionados à forragem e ao uso de fontes alternativas de energia para suplementos múltiplos. Uniciências, Cuiabá, v. 14, n. 2 , p. 241-270, 2010.

CATTELAM, J.; BRONDANI, I. L.; ALVES FILHO, D. C.; PACHECO, P. S.; SEGABINAZZI, L. R.; PIZZUTI, L. A. D.; CAllegaro, A. M.; PACHECO, R. F.; MAYER, A. R.; CARDOSO, G. S.; BORCHATE, D.; TEIXEIRA, O. S. Comportamento social, frequência respiratória e escore de limpeza de novilhos confinados com diferentes espaços individuais. Revista Acadêmica Ciências Agrárias e Ambiental, Curitiba, v. 12, n. 1, p. 51-60, 2014.

CORREAA, L. A. Produção intensiva de carne bovina em pastagens sob pastejo rotacionado. In: ENCONTRO DE MÉDICOS VETERINÁRIOS DOS VALES MUCURI, JEQUITINHONHA E RIO DOCE, SIMPÓSIO DE ATUALIZAÇÃO TÉCNICA DO NORDESTE MINEIRO, 22.; 2., 2001, Teófilo Otoni. Anais... Teófilo Otoni: SRMV/MG, 2001. p. 8-12.

D'OCCHIO, M. J.; ASPDEN, W. J.; TRIGG, T. E. Sustained testicular atrophy in bulls actively immunized against GnRH: potential to control carcase characteristics. Animal Reproduction Science, Amsterdam, v. 66, n. 1/2, p. 47-58, 2001.

DUNSHEA, F. R.; SOUZA, D. N.; PETHICK, D. W.; HARPER, G. S.; WARNER, R. D. Effects of dietary factors and other metabolic modifiers on quality and nutritional value of meat. Meat Science, Amsterdam, v. 71, n. 1, p. 8-38, 2005.

EMERENCIANO NETO, J. V.; DIFANTE, G. S.; MONTAGNER, D. B.; BEZERRA, M. G. S.; GALVÃO, 
R. C. P.; VASCONCELOS, R. I. G. Características estruturais do dossel e acúmulo de forragem em gramíneas tropicais, sob lotação intermitente e pastejada por ovinos. Bioscience Journal, Uberlândia, v. 29, n. 4, p. 962-973, 2013.

EUCLIDES, V. P. B.; MACEDO, M. C. M.; OLIVEIRA, M. P. Avaliação de diferentes métodos de amostragem sob pastejo. Revista Brasileira de Zootecnia, Viçosa, MG, v. 21, n. 1, p. 691-702, 1992.

FERNANDES, G. A.; FERNANDES, F. F. D.; MOUSQUER, C. J.; OLIVEIRA, E. B.; CASTRO, W. J. R.; SILVA FILHO, A. S. Produção de novilhos superprecoce a pasto: uma revisão. Revista Brasileira de Higiene e Sanidade Animal, Fortaleza, v. 9, n. 3, p. 553$579,2015$.

FRASER, A. F.; BROOM, D. M. Farm animal behavior and welfare. $3^{\text {th }}$ ed. London: CAB International, 2002. $437 \mathrm{p}$.

FREITAS, V. M.; LEÃO, K. M.; ARAUJO NETO, F. R.; MARQUES, T. C.; FERREIRA, R. M.; GARCIA, L. L. F.; OLIVEIRA, E. B. Efeitos da castração cirúrgica, imunocastração e homeopatia sobre o desempenho, características de carcaça e comportamento de bovinos machos cruzados terminados em confinamento. Semina: Ciências Agrárias, Londrina, v. 36, n. 3, p. 1725-1734, 2015.

GLIENKE, C. L.; ROCHA, M. G.; CAMARGO, D. G.; PÖTTER, L.; CONFORTIN, A. C. C.; COSTA, V. G. Grazing ecology of female lambs on Italian ryegrass plus red clover pasture under different defoliation intensities. Revista Brasileira de Zootecnia, Viçosa, MG, v. 39, n. 1, p. 51-60, 2010.

GOMES, R. A.; LEMPP, B.; JANK, L.; CARPEJANI, G. C.; MORAIS, M. G. Características anatômicas e morfofisiológicas de lâminas foliares de genótipos de Panicum maximum. Pesquisa Agropecuária Brasileira, Brasília, v. 46, n. 2, p. 205-211, 2011.

GONZÁLEZ, L. A.; FERRET, A.; MANTECA, X.; TORRE, J. L. R.; CALSAMIGLIA, S. M.; DEVANT, M.; BACH, A. Performance, behavior, and welfare of Friesian heifers housed in pens with two, four, and eight individuals per concentrate feeding place. Journal of Animal Science, Champaign, v. 86, n. 6, p. 1446-1458, 2008.

HERNANDEZ, J. A.; ZANELLA, E. L.; BOGDEN, R.; AVILA, D. M.; GASKINS, C. T.; REEVES, J. J. Reproductive characteristics of grass-fed, luteinizing hormone-releasing hormone-immunocastrated Bos indicus bulls. Journal of Animal Science, Champaign, v. 83, n. 12, p. 2901-2907, 2005.
HODGSON, J.; BROOKES, I. M. Nutrition of grazing animals. In: WHITE, J.; HODGSON, J. New Zealand pastures and crop sciences. New York: Oxford University, 1999. p. 117-132.

INSTITUTO NACIONAL DE METEOROLOGIA INMET. BDMEP - Banco de dados meteorológicos para ensino e pesquisa. Brasília: [s.n.], 2015. Disponível em: $<$ http://www.inmet.gov.br/portal/index. php?r=bdmep/ bdmep>. Acesso em: 28 out. 2015.

ÍTAVO, L. C. V.; DIAS, A. M.; ÍTAVO, C. C. B. F.; EUCLIDES FILHO, K.; MORAIS, M. G.; SILVA, F. F.; GOMES, R. C.; SILVA, J. P. B. Desempenho produtivo, características de carcaça e avaliação econômica de bovinos cruzados, castrados e não castrados, terminados em pastagens de Brachiaria decumbens. Arquivo Brasileiro de Medicina Veterinária e Zootecnia, Belo Horizonte, v. 60, n. 5, p. 1157-1165, 2008.

JAGO, J. G.; BASS, J. J.; MATTHEWS, L. R. Evaluation of a vaccine to control bull behaviour. Proceedings of the New Zealand Society of Animal Production, Napier, v. 57, n. 1, p. 91-95, 1997.

JANETT, F.; GERIG, T.; TSCHUOR, A. C.; AMATAYAKUL-CHANTLER, S.; WALKER, J.; HOWARD, R.; PIECHOTTA, M.; BOLLWEIN, H.; HARTNACK, S.; THUN, R. Effect of vaccination against gonadotropin-releasing factor $(\mathrm{GnRF})$ with Bopriva ${ }^{\circledR}$ in the prepubertal bull calf. Animal Reproduction Science, Amsterdam, v. 131, n. 1/2, p. 72-80, 2012.

KAY, M.; HOUSEMAN, R. The influence of sex on meat production. In: COLE, D. J. A.; COLE, E.; LAWRIE, R. A. Meat. London: Butterworths, 1975. p. 85-108.

KLINGMANN, D. L.; MILES, S. R.; MOTT, G. O. The cage method for determining consumption and yield of pasture herbage. American Society of Agronomy, Geneva, v. 35, n. 9, p. 739-746, 1943.

KRYSL, L. J.; HESS, B. W. Influence of supplementation on behavior of grazing cattle. Journal of Animal Science, Champaign, v. 71, n. 9, p. 2546-2555, 1993.

LEE, C.; FISHER, A. D.; COLDITZ, I. G.; LEA, J. M.; FERGUSON, D. M. Preference of beef cattle for feedlot or pasture environments. Applied Animal Behaviour Science, Amsterdam, v. 145, n. 3/4, p. 53-59, 2013.

LICITRA, G.; HERNANDEZ, T. M.; VAN SOEST, P. J. Standardization of procedures for nitrogen fractionation of ruminant feeds. Animal Feed Science and Technology, Amsterdam, v. 57, n. 4, p. 347-358, 1996.

LOPES, M. A.; ROSA, L. V.; SANTOS, G.; LOPES, N. M. Efeito da castração sobre o desempenho e rentabilidade da terminação de bovinos de corte em confinamento de 
aluguel. Boletim da Indústria Animal, Nova Odessa, v. 68, n. 1, p. 75-80, 2011.

MARTI, S.; DEVANT, M.; AMATAYAKULCHANTLER, S.; JACKSON, J. A.; LOPEZ, E.; JANZEN, E. D.; SCHWARTZKOPF-GENSWEIN, K. S. Effect of anti-gonadotropin-releasing factor vaccine and band castration on indicators of welfare in beef cattle. Journal of Animal Science, Champaign, v. 93, n. 4, p. 1581-1591, 2015.

MENEZES, L. F. G.; RESTLE, J.; KUSS, F.; BRONDANI, I. L.; ALVES FILHO, D. C.; CATELLAM, J.; OSMARI, M. P. Medidas corporais de novilhos das gerações avançadas do cruzamento rotativo entre as raças Charolês e Nelore, terminados em confinamento. Ciência Rural, Santa Maria, v. 38, n. 3, p. 771-777, 2008.

MINSON, D. J. Forage in ruminant nutrition. New York: Academic Press, 1990. 483 p.

MOTT, G. O.; LUCAS, H. L. The design conduct and interpretation of grazing trials on cultivated and improved pastures. In: PROCEEDINGS OF THE INTERNATIONAL GRASSLAND CONGRESS, 1952, Pennsylvania. Proceedings... Pennsylvania: State College, 1952. p. 1380-1395.

NATIONAL RESEARCH COUNCIL - NRC. Nutrient requirements of beef cattle. $7^{\text {th }}$ ed. rev. Washington: National Academy Press, 2000. 242 p.

OLIVEIRA, C. B.; BORTOLI, E. C.; BARCELlOS, J. O. J. Diferenciação por qualidade da carne bovina: a ótica do bem-estar animal. Ciência Rural, Santa Maria, v. 38, n. 7, p. 2092-2096, 2008.

OSORIO, J. P.; JARAMILLO, L. C. J.; ARROYO, R. J. O.; ÁlVAREZ, J. C.; SOUZA, F. A. Relación entre la circunferencia escrotal, el crecimiento testicular y parámetros de calidad de semen en toros de raza Guzerat, desde la pubertad hasta los 36 meses de edad. Revista de Medicina Veterinaria, Bogotá, n. 27, p. 73-87, 2014.

PACHECO, R. F.; ALVES FILHO, D. C.; BRONDANI, I. L.; NORNBERG, J. L.; PIZZUTI, L. A. D.; CALlEGARO, A. M. Características produtivas de pastagens de Milheto ou capim Sudão submetidas ao pastejo contínuo de vacas para abate. Ciência Animal Brasileira, Goiânia, v. 15, n. 3, p. 266-276, 2014.

POMPEU, R. C. F. F.; CÂNDIDO, M. J. D.; LOPES, M. N.; GOMES, F. H. T.; LACERDA, C. F.; AQUINO, B. F.; MAGALHÃES, J. A. Características morfofisiológicas do capim-Aruana sob diferentes doses de nitrogênio. Revista Brasileira de Saúde e Produção Animal, Salvador, v. 11, n. 4, p. 1187-1210, 2010.
PÖTTER, L.; ROCHA, M. G.; ROSO, D.; COSTA, V. G.; GLIENKE, C. L.; ROSA, A. N. Suplementação com concentrado para novilhas de corte mantidas em pastagens cultivadas de estação fria. Revista Brasileira de Zootecnia, Viçosa, MG, v. 39, n. 5, p. 992-1001, 2010.

PRICE, E. O.; ADAMS, T. E.; HUXSOLL, C. C.; BORGWARDT, R. E. Aggressive behavior is reduced in bulls actively immunized against gonadotropin-releasing hormone. Journal of Animal Science, Champaign, v. 81, n. 2, p. 411-415, 2003.

REIS, R. A.; RUGGIERI, A. C.; OLIVEIRA, A. A.; AZENHA, M. V.; CASAGRANDE, D. R. Suplementação como estratégia de produção de carne de qualidade em pastagens tropicais. Revista Brasileira de Saúde e Produção Animal, Salvador, v. 13, n. 3, p. 642-655, 2012.

RODRIGUEZ, J.; UNRUH, J.; VILLARREAL, M.; MURILlO, O.; ROJAS, S.; CAMACHO, J.; JAEGER, J.; REINHARDT, C. Carcass and meat quality characteristics of Brahman cross bulls and steers finished on tropical pastures in Costa Rica. Meat Science, Amsterdam, v. 96, n. 3, p. 1340-1344, 2014.

SANTOS, D. T.; CARVALHO, P. C. F.; NABINGER, C.; CARASSAI, I. J.; GOMES, L. H. Eficiência bioeconômica da adubação de pastagem natural no sul do Brasil. Ciência Rural, Santa Maria, v. 38, n. 2, p. 437444, 2008.

SANTOS, M. D. S.; REGO, F. C. A.; RODRIGUES, M. V. L.; COSTA, D. S.; SOUZA, C. N.; CUNHA FILHO, L. F. C.; BELAN, L.; ZUNDT, M.; SANTANA, J. L. Terminação de bovinos Brangus inteiros e castrados com cana-de-açúcar (Saccharum officinarum) ou silagem de capim mombaça (Panicum maximum cv mombaça). Colloquium Agrariae, Presidente Prudente, v. 10, n. 1, p. 45-54, 2014.

SILVA, C. C. F.; BONOMO, P.; PIRES, A. J. V.; MARANHÃO, C. M. A.; PATÊS, N. M. S.; SANTOS, L. C. Características morfogênicas e estruturais de duas espécies de braquiária adubadas com diferentes doses de nitrogênio. Revista Brasileira de Zootecnia, Viçosa, MG, v. 38, n. 4, p. 657-661, 2009.

THEUBET, G.; THUN, R.; HILBE, M.; JANETT, F. Wirkung einer Impfung gegen GnRH (Bopriva $\left.{ }^{\circledR}\right)$ beim männlichen pubertären Kalb. Schweizer Archiv für Tierheilkunde, Zurich, v. 152, n. 10, p. 459-469, 2010.

VAN SOEST, P. J.; ROBERTSON, J. B.; LEWIS, B. A. Methods for dietary fiber, neutral detergent fiber, and nonstarch polysaccharides in relation to animal nutrition. Journal of Dairy Science, Champaign, v. 74, n. 10, p. 3583-3597, 1991. 
VAZ, F. N.; RESTLE, J.; PÁDUA, J. T.; MORALES, D. C. S. P.; PACHECO, P. S.; MAYSONNAVE, G. S. Características de carcaça e da carne de bovinos mestiços não castrados ou submetidos a diferentes métodos de castração. Ciência Animal Brasileira, Goiânia, v. 15, n. 4, p. 428-436, 2014.

VITTORI, A.; GESUALDI JÚNIOR, A.; QUEIROZ, A. C.; RESENDE, F. D.; ALLEONI, G. F.; RAZOOK, A. G.; FIGUEIREDO, L. A. Desempenho produtivo de bovinos de diferentes grupos raciais, castrados e não castrados, em fase de terminação. Arquivo Brasileiro de Medicina Veterinária e Zootecnia, Belo Horizonte, v. 59, n. 6, p. 1263-1269, 2007.

VITTORI, A.; QUEIROZ, A. C.; RESENDE, F. D.; GESUALDI JÚNIOR, A.; ALLEONI, G. F.; RAZOOK, A. G.; FIGUEIREDO, L. A.; GESUALDI, A. C. L. S. Características de carcaça de bovinos de diferentes grupos genéticos, castrados e não castrados, em fase de terminação. Revista Brasileira de Zootecnia, Viçosa, MG, v. 35, n. 5, p. 2085-2092, 2006.

WEBSTER, H. B.; MORIN, D.; JARRELL, V.; SHIPLEY, C.; BROWN, L.; GREEN, A.; WALLACE, R.; CONSTABLE, P. D. Effects of local anesthesia and flunixin meglumine on the acute cortisol response, behavior, and performance of young dairy calves undergoing surgical castration. Journal of Dairy Science, Champaign, v. 96, n. 10, p. 6285-6300, 2013.

WEISS, W. P.; CONRAD, H. R.; PIERRE, N. R. St. A theoretically-based model for predicting total digestible nutrient values of forage and concentrates. Animal Feed Science and Technology, Amsterdam, v. 39, n. 1/2, p. 95110, 1992.

WILM, H. G.; COSTELlO, D. F.; KLIPPLE, G. E. Estimating forage yield by the doublesampling methods. Journal of the American Society of Agronomy, Madison, v. 36, n. 3, p. 194-203, 1944.

ZANELLA, R.; ZANELLA, E. L.; REEVES, J. J.; HERNANDEZ, J.; MOTTA, A. C.; AVILA, D. Características testiculares de touros imunizados com vacina anti-hormônio liberador do hormônio luteinizante. Pesquisa Agropecuária Brasileira, Brasília, v. 44, n. 10, p. 1359-1363, 2009.

ZANINI, G. D.; SANTOS, G. T.; SCHMITT, D.; PADILHA, D. A.; SBRISSIA, A. F. Distribuição de colmo na estrutura vertical de pastos de capim Aruana e azevém anual submetidos a pastejo intermitente por ovinos. Ciência Rural, Santa Maria, v. 42, n. 5, p. 882$887,2012$. 
